\title{
English Café: An Initiative to Encourage Undergraduate Learners of Al- Asyah Province to Showcase Their Spoken Proficiency in English
}

\author{
Syed Farhat Jahara ${ }^{1}$ and Abbas Hussein Abdelrady \\ Qassim University, Kingdom of Saudi Arabia
}

\begin{abstract}
This article advocates that spoken language is learned only when genuine communication and exposure occur, not when it is practiced simply as a set of structures or only when its grammar is learned. This research study demonstrates the possibility of exploring novel approaches to inspire non-native EFL learners in the Al-Qassim region of Saudi Arabia to master communication skills by establishing a linguistic club named English Café to showcase their spoken proficiency. The study sample consisted of undergraduates from level 1 and level 2 from the first year of the B.A. program. The methodology adopted was a descriptive-analytical method using a questionnaire and spoken activities to achieve the desired objectives. One major finding was that participants improved their communicative competence by participating in pronunciation and speaking activities through constant motivation, preferred learning style, self-interest, and willingness to participate naturally with expert guidance initially and constant practice after that.
\end{abstract}

Keywords: Activities, communicative competence, EFL learners, English Café, pronunciation, strategies.

Alhawsawi (2014) notes that in today's world, knowledge is a powerful tool; it is the capital that has the ability to transform the nation including both teachers and learners. The teaching of the English language depends on the prospective excellence, skills, and knowledge of teachers. An English instructor's role in the present context has changed because of social, cultural, economic, and technological developments across the globe. English teachers must be innovative, inventive, and ingenious to adopt new techniques to change the social stature and mindset of learners, and the difficulties teachers face are large. Due to globalization, the world is changing rapidly; hence, an English teacher has to improve and update knowledge and employ innovative techniques to meet the demands of a changing era.

Teaching is a dynamic profession changing in line with the necessities of the era (Wallace, 1991). A teacher's pivotal role is to shape the future of today's students, with good language skills is the backbone of every successful graduate. It is a vehicle used for diverse purposes. Hence, an English teacher must be smart enough to provide an appropriate remedy to enable learners to improve their communication to enhance their social status and employability. Today's language teachers have a good grounding in various techniques and novel methods, and the application of these methodologies and approaches helps in learning the context to obtain the desired objectives. The teacher's central role lies in the awareness-raising and providing a variety of learning processes so that learners develop strategic competencies for language learning. An English teacher must

${ }^{1}$ Correspondent Author E-Mail: fa.syed@qu.edu.sa 
showcase a diversity of responsible roles as a curriculum designer, planner, mentor, facilitator, motivator, and language expert (Jahara, 2012). English teachers are also expected to keep up with the changing demands of lifestyle in the course of time and they assume different roles depending upon the crowd of classes, learner characteristics, and the nature of the activity and physical appearance of the classroom. The changing role of teachers is especially important in foreign language teaching contexts (Atmaca, 2018).

\section{Background}

The establishment of the education system in Saudi Arabia dates to 1926 to the teaching of schoolboys. The Ministry of Education was established in 1952 during the rule of King Saud bin Abdul-Aziz Al Saud. It was an extension and development of the Knowledge Directorate. It was founded to plan and supervise public education for boys in its three levels primary, intermediate, and higher secondary. After the success of the boy's education policy, the General Presidency for girls' education was established in 1959 during the rule of King Saud bin Abdul-Aziz Al Saud. Later, in 1975, the Ministry of Higher Education was established. The Ministry of Education has incorporated EFL into Saudi Arabian education system as an obligatory beginning at primary school from grade four to the university level according to the new education policy (Ministry of Education, n.d).

The Ministry of Education has approved seven different EFL syllabi to be taught in Saudi schools from 2015 in Riyadh, Jeddah, Qassim, and Eastern region. The curriculum approved by the new education policy uses MM publications, McGraw Hill, Macmillan, Longman, Oxford, EF publications, and Saudi Arabian books. The Ministry has also modernized the school curriculum and provided teacher training centers to develop school teachers with modern, up-to-date teaching methodologies.

The new Saudi education system has increased students' exposure to English at all levels due to changes in education policies and modernized curriculum. The students get familiarized with EFL at grade four in their primary school, with each session being 35 minutes taught twice a week and followed for sixteen weeks per semester. During this stage, the students learn from the Get Ready, We Can, and Smart Class curriculum of primary schools for three years. Then, students study EFL for another three years at their intermediate school from the books named Full Blast, Lift off, and Super Goal. Finally, they acquire three more years of EFL training in their higher secondary school from the books named Mega Goal, Flying High, and Traveller. The total number of years a Saudi student spends in learning EFL is about nine years in their overall school education.

After their higher secondary school, when these students register for the B.A. program to study the English language in the affiliated colleges of Qassim University, they need to complete an intensive course consisting of vocabulary building, basic grammar, reading, writing, listening, and speaking skills for one semester with an average qualifying mark of 300 or have an IELTS score of 6 to get directly admitted into the first-year of a B.A. The four-year B.A. program aims to prepare the graduates and equip them with skills and experience in the English language and translation.

Despite all these years of learning and exposure to EFL, most students from Al-Asyah province cannot engage in day-to-day conversations in the English language and have a very low communicative competence level. They are inhibited and lack confidence in communicating with their teachers and peer group. They also feel anxious about their inability to communicate with others in English language. All these fears and inhibitions raise emotional anxiety and hinder the learners' efforts at language acquisition. Therefore, the issue of EFL in this country is approached 
from EFL teachers' perspective with a high level of expertise in teaching and learning English in Saudi Arabia (Tzvetomira, 2020).

In recent years much research has been carried out on the challenges and problems of learning English as a second and foreign language in many parts of the world. Unfortunately, these studies did not take place in the Arab region or the Saudi Arabian Peninsula.

Until recently, many Saudi Arabian students were not keen on acquiring the English language and took it for granted. However, many students have recently changed their attitudes towards the English language and have a strong desire to acquire English, and the human capital development program of Saudiasation and Vision 2030 has promoted this skill acquisition. Given this growing demand for the English language and to enrich the language skills of Al-Asyah learners, we established a linguistic club named the English Café in our college to encourage students to participate in innovative activities to enrich their developmental skills and showcase their communicative ability. The activities for English Café were selected, keeping in view the needs of the undergraduate students to enrich their spoken proficiency.

\section{Research Questions}

This research study focuses on the implementation of selected activities in an English Café. Focusing on speaking proficiency, the following questions were addressed.

RQ1. What is the importance of communicative competence for undergraduates?

RQ2. To what extent does content knowledge help in understanding and comprehending a spontaneous spoken activity?

RQ3. What were the perceptions of each student towards the speaking activities?

RQ4. What strategies are the most successful?

\section{Methodology}

\section{The Qassim University Curriculum Program}

In Qassim University's curriculum, the B.A. program is designed with 127 total credit hours to complete undergraduate studies in the English Language and Translation Department. The students complete learning through their study time, in-class participation, assignments, projects, presentations, and library work with 3 credit hours for each course and 15 to 18 hours of learning each week per semester. The university's curriculum aims to develop speaking, reading, writing, and listening skills through individual, pair, and group activities, thereby refining a student's communicative ability regarding everyday matters in EFL.

The target group selected for this research study were undergraduates from the B.A. in the first year, belonging to levels 1 and 2. The B.A program seeks to prepare the undergraduates and equip them with skills and acquaintance in the English language, translation studies to qualify as teaching assistants, researchers, producers of knowledge, and trainers to deal with technology, creative thinking, and problem-solving. 


\section{Participants}

The sixty participants of the research study chosen were 25 from level 1 and 35 from level 2. These participants were a homogeneous group of undergraduate learners from B.A. first year, non-native speakers of English coming from the diverse socio-economic and cultural background from different regions of Al-Asyah province, like Qibah, Altanoma, Hunayzil, Al-Jalah, Modarraj, Talha, Alworood, and Khusaiba in the Al-Qassim region. The study sample involved participants from the College of Sciences and Arts from Qassim University, where English is learned as an EFL. All learners in these levels were female participants, ranging in age from 17 to 20 .

Before students participated in English Café activities, each student filled in a questionnaire to seek background information and their interest in participating in English Café. This method helped the researchers obtaining information about the students and helped the researchers understand learners' perceptions concerning the listening and speaking process, comprehending spoken activity, and the different strategies that learners used to understand speaking skills. All the participants filled in the questionnaire, and their answers were collected and scored.

The participants were chosen by filling a questionnaire and through classroom observation. The chosen participants were encouraged to participate in English Café due to their English language problems like fear to communicate, fossilized pronunciation errors in day-to-day vocabulary usage, spelling errors, low communicative competence to express their ideas, and inadequate reading ability before joining the English Café. The researchers taught the participants academic writing and reading courses, and therefore participants were encouraged to join English Café to improve their language skills by taking extra training for one semester to practice language skills under expert supervision.

\section{Procedure}

The researchers work as faculty in English in the College of Sciences and Arts at Qassim University in Al-Asyah. To create a tension-free learning atmosphere for female undergraduates, a linguistic club named English Café was established. The linguistic club has an excellent ambience to welcome learners to spend their valuable time creatively by being involved in communicative activities.

\section{Learning Styles}

A "learning style has both a cognitive and an affective dimension and thus reflects the totality of psychological functioning" (Willing, 1987) as cited by (Ellis, 1994, p. 534), and every student has her learning style, and these learning styles differ across learners (Dunn \& Griggss, 2000). For example, some learners like to learn by looking at things or information such as pictures, diagrams, cartoons, and demonstrations (visual learners), and some prefer to hear and comprehend information (auditory learners). In contrast, some other learners like to learn by doing things (kinesthetic learners), and some others prefer to study in groups or individually (tactile learners). Our English team pulled together learner's preferences from this inventory, it enabled us to organize matching activities to involve participants in English Café.

According to (Khaled \& Lynne, 2003), individual differences have essential effects on learners' behavior (Riding \& Rayner, 1998). These differences include gender (Ford \& Miller, 1996), system experience (Holscherl \& Strubel, 2000), prior knowledge and spatial ability (Mayer 
\& Gallini, 1990), occupational experience (Durling et al., 1996) and cognitive styles (Durfresne et al., 1999).

The researchers in English Café implemented a learning style inventory designed by (Reid, 1987), and (Richards \& Lockhart, 1996), to know the participants preferred learning styles. The learning style inventory results indicated that most of our participants preferred visual, auditory, tactile and kinesthetic aspects in their major learning activity. Therefore, we planned our pronunciation, listening and speaking activities based on the learners' preference and we also took feedback from the participants on how they would prefer to participate in the English Café.

This inventory was used to help the researchers manage the English Café during the implementation of activities. Appropriate learning style recognition becomes essential for researchers because if a learner has an individual learning style and is asked to work in the group or pair works, she might be psychologically affected. Her mental state may hinder her actual performance, and as a result, the finding may not portray the actual picture. Therefore, to avoid such an unusual situation, the learning style inventory was used to enhance all the teaching and learning activities in the English Café.

\section{Psychological Factors}

\section{Motivation}

Motivation can be defined as a determination a learner makes to acquire language. (Ellis, 2004). It is necessary to motivate the learners before initiating an activity, as motivation prepares the students to concentrate in the classroom and make them think and actively participate in various activities in the English Café. The learners also develop a stronger desire to interact, and they are likely to listen and respond. It is important to remember that learners with attention divergence may not participate in activities efficiently as they do not know how to use their intellectual energy effectively. According to Xiao (2014), a teacher's motivation is necessary for primary or secondary education with a noticeable paucity of attention given to university instructors.

This research study found it is necessary to motivate and help the learners in participation and spoken involvement. English teachers should always applaud the learners' attention, and when the learners are in a state of alertness, the teachers should make their process efficient. To enable learners to keep their attention focused, a teacher must clearly define the activity's aim. Wellstructured activities will arouse participants' attention, help learners focus, and keep their processing skills function. Understanding the learner's strengths and weaknesses and slightly modifying the teaching methods may move many incompetent speakers of EFL along their erudition curve to enrich their spoken proficiency.

\section{Anxiety}

"Foreign language anxiety constitutes a particular kind of situational anxiety. The foreign language classroom anxiety scale (Horwitz \& Cope, 1986) focused on general foreign language classroom anxiety emphasizing oral communication" as cited by (Ellis, 1994, p. 539). The undergraduate female learners of the B.A. program of Al-Asyah province have already studied English as an EFL and an obligatory option during their last year of primary, intermediate, and higher secondary school, but they have not attained conversational skills and other nuances despite learning for seven years. 
According to Demir \& Zaimoğlu (2021), foreign language anxiety and decision-making vary in terms of gender, language background, high school background and exposure to English levels separately. Learners of the vernacular medium are very incompetent speakers of EFL. Most learners know grammar and structures, but they are nervous, shy, and hesitant to communicate with in the peer group and outside. They consider English as a foreign language, and hence they are hesitant to speak in English due to a lack of practice, guidance, and sufficient exposure to develop their linguistic and communicative competence. The learners hesitate to express their ideas lest they commit mistakes. They are inhibited and worried about criticism from the peer group. The researchers tried to make the participants feel free in English Café from their anxiety level and open up to participate. A participant's ability to understand and responding to the desired input is an example to evaluate their spoken proficiency.

\section{Willingness to Communicate}

According to Maclntyre et al. (2001), "willingness to communicate can be defined as an intention to initiate communication, given by a choice" as cited by (Ellis, 1994, p. 542). Learners with a strong willingness are likely to benefit more than those who are shy.

Communication is a very basic human need and activity. It is a vehicle that keeps us in contact with the transfer of information and understanding of people around us. It may be defined as formal talk in which people exchange news, views, thoughts, feelings, and so on (Pellicer et al., 2020).

Communication is the backbone of our life. It is a skill that we all need to convey our needs, desires, choice, views, knowledge, emotions, ideas, and so on. It is an expression of our selfidentity in all spheres of life. It is one of the pre-requisites of recruitment nowadays. Some areas like teaching, human resource, public relations, marketing, sales, and customer care call for a high communication proficiency level. In the same way, learners of Al-Asyah province too need them according to the growing demand of the Saudiasation and Vision 2030 (2021) drive in Saudi Arabia.

Many students consider effective communication skills to be one of the important skills for effective performance at work. In the global context, the language used for communication must be clear, direct, and simple, and the responses must be quick and prompt. Professionals today need to express their ideas concisely and forcefully. A lack of communication skills can be seen to hurt learners' accessibility to communication networks. Therefore, to develop speaking and listening skills, our linguistic club organized all the previously discussed activities and helped Al-Asyah province's students participate willingly in English Café and the responses were appreciable.

\section{Activities}

After the formal inauguration of the English Café, the linguistic club started introducing wide-ranging communicative activities. The researchers conducted associated activities from the curriculum of B.A. first year to the participants of levels 1 and 2 throughout the study. Students participated in pronunciation, word-building, speaking, and listening proficiency activities and used only the English language in the Café to showcase their spoken proficiency. Students participated in practicing sounds, phonemic word square, pictionary, tic-tac-toe, charades, and brainstorming to enrich their pronunciation and vocabulary building. Likewise, poem recital, storytelling, role-play, extempore (Just a minute), ice breaker chain, ad-show, collage presentation, photoshoot description, group discussion, and the Chinese whispers game were designed to develop 
speaking and listening proficiency. All activities were made clear for presentation, and the researchers interacted with them continuously to clarify their suspicions and gave suggestions to participate.

According to Stern (1992), instruction would be more useful and facilitates second language learning when learners are given ample opportunities to listen, speak, read and write in the classroom. This kind of exposure to the language skills in the classroom enables the participants to refine their own language and also make them understand the day-to-day language heard in different situations.

The participants used self-supporting strategies owing to a lack of exposure and practice in the English language while working on listening and speaking activities. Listening and speaking strategies are techniques or activities that contribute directly to the comprehension and recall of input. These strategies play a central role in the training and learning process and might hold for receptive and productive communication strategies.

\section{Pronunciation and Word-building Activities}

Practicing sounds: At the beginning, to motivate students to participate in English Café and develop the perception of sounds, particularly the pronunciation, they were encouraged to recite the sounds of English with examples with their teacher. To introduce this activity, we included consonants and vowels phonemes with some sample words "for example /p/ pay, / b/ back, /s/ sue, /z/ zoo - and so on" (Hancock, 2003, pp. 11-16). Comparative words "for example /a:/ car-far, / $\mathrm{N} /$

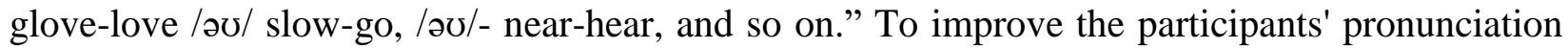
and listening skills, the researchers gave articulatory description of the sounds and oral training with the help of a mic.

Phonemic word square: To enrich English pronunciation, phonemic word square was introduced with missing phonemes to be identified and added to phonemic word squares to create meaning full words. The researchers introduced examples from "English short and long vowels "to the participants and asked them to guess the words related with short and long vowels "for example/i:/ beach, / o:/ talk, / e/ sell, / æ/ cap, / $/$ cut and so on" (Hancock, 2003, p. 136). The participants need to correct the missing phonemes in the phonemic word squares within the time limit and produce meaningful words. This language game can be adapted to teach any vocabulary item, and it is a great way to teach English pronunciation more clearly and distinctively.

Pictionary: To develop an art of imagination and vocabulary building, pictionary was introduced. Pictionary is great fun in the classroom at all levels to learn new words with the help of pictures. The participants were split into two groups to introduce this activity, and one participant from each team comes and picks up a card with a picture. "The pictures were chosen from the curriculum" (Hancock, 2003, p. 13). They return to their team to draw the picture and show it to other group participants. The team members have to guess the picture for each new vocabulary item introduced. It helped participants to focus on drawing the picture clearly and mime to guess the word.

Tic-tac-toe: To polish our participant's vocabulary tic-tac-toe, an entertaining vocabulary board game was introduced. This game can be adapted to teach vocabulary in an interesting method to make meaningful full sentences. A board is prepared, and tic-tac-toe squares are drawn for the participants to write meaningful sentences on lexical ties. The participants were given "nouns, verbs, adjectives and adverbs" (Hartmann et al., 2012, p. 21), to make meaningful sentences of 
their own and say them aloud to cross each grid with a correct sentence to complete the tic-tac-toe squares.

Charades: Charades was introduced to develop vocabulary building. In the game of charades, participants communicate clues of the given vocabulary nonverbally with their teammates by maintaining good eye contact from time to time with a good posture. The participant has to mime the given vocabulary list to their team, like "headache, stomachache, wrinkles, smoke, overweight, heart, healthy, chronic and so on" who try to guess the clue correctly within the time limit (Hartmann et al., 2012, p. 78). One of the participants enacts the clue repeatedly until the team correctly identifies the word. The art of miming involves acting skills through body moments without the use of speech. This guessing activity helps the participants to focus attention and develop facial expressions and gestures while performing their tasks (Rahmah \& Astutik, 2020).

Brainstorming: Brainstorming was introduced to link images and key concepts to develop vocabulary building. It is a process in which participants strive to stimulate and generate ideas creatively, applying critical thinking skills as cited by (Jahara, 2013). The participants were asked to "brainstorm their ideas on the food they like in a word web connecting with name, taste, smell, appearance, types, preparation, and context" (Savage \& Mayer, 2012). All the participants showed interest in talking about their favorite food using good vocabulary, ingredients needed for preparation, taste and smell, preparation time, food type, and the context where it is served. This activity helped the participants think in minute details about the list of words and ingredients needed for food preparation.

\section{Speaking and Listening Activities}

Poem recital: Poem recital was introduced to develop presentation skills. Participants were given a lyric poem by Robert Burns, "My Love is Like A Red, Red Rose" (Savage \& Mayer, 2012, p. 40). Poetry is not meant to be read silently to oneself; it is meant to be heard. The best way to understand poetry is to recite it. This involves good pace, rhythm, tone, and delivery. Reciting poetry aloud is also a great exercise in public speaking as learners showcase their nonverbal communication clues, physical presence, tone of voice, and style of delivery skill that most of our students are sadly lacking. Learning to speak clearly and beautifully in public is an invaluable skill for today's students (Mooney \& Little, 2020).

Storytelling: Storytelling was introduced to develop the art of public speaking. Participants were given the genre to tell their "best fact or fiction" (Tanka \& Most, 2009), story using the following guidelines; a well-designed setting, artistic description of characters, a mystery to solve, the climax of the story, and resolution. Storytelling can motivate participants because it lowers their anxiety and fosters creative talent in producing literary content with their imagination and fantasy. Likewise, few participants created their best nonfiction stories with their amazing introduction, setting, storyline, catchy outline, creative content, artistic characters, peak action, vivid descriptions, and resolution. This activity encourages participants in critical thinking and narrative details of the events.

Role-play: Role-play was introduced to inculcate self-awareness and gratitude. Role-play involves imitating a character with a well-designed setting, good voice modulation, effective dialogue delivery using facial expressions, eye contact, and body moments. The participants were made into teams, and each team was given a theme, "Save the Environment" (Tanka \& Most, 2009). Each team worked on the environment's hazards and used placards to show their message, saying that every individual is responsible for reducing plastics usage. They also gave awareness 
to reuse things. Plastic bottles were transformed into beautiful flower vases, and used bangles and laces were used as decorative pieces of art by giving them a makeover.

Extempore (JAM/ Just a minute): To develop spontaneity with good communication skills, grammar, appropriate word order, an extempore activity named JAM was conducted on the topic "smile". Just a minute session is assessed on the parameters of content knowledge, vocabulary, accent, creativity, and nonverbal communication of the participants. This activity makes the participants focus on minute details without repetition and deviation to speak effectively within the time limit.

Ice breaker chain: To develop attentive listening ability with amusement, an ice breaker chain named self-introduction using a bar of chocolate was introduced. The participants were asked to introduce themselves by adding a bar of chocolate to their name with their first letter. The participants have to introduce themselves and their team members without breaking the chain. This activity has an overwhelming response from our participants, and they enjoyed it. This activity will help participants to introduce themselves and know each other to share their views while participating as a team (Amrullah, 2015).

Ad-show: Ad-show was introduced to develop the art of public speaking, acting skills, dialogue delivery, and nonverbal communication. A few thought-provoking words penned down on a piece of article can change students approach towards life. To achieve this objective, the participants were made into teams, and each team was given a product to create their own "interesting and boring" commercials (Tanka \& Most, 2009, p. 155). Participants created effective message-oriented interesting, and persuasive commercials, making the audience experience a wide variety of facial expressions and emotions to advertise their products and services. Most of the teams have tried to generate laughter, creating very funny, tongue-in-cheek commercials. However, one team shaped a dramatic, thought-provoking commercial, a public service announcement against the hazards of junk food which is in demand in educational institutions' cafeterias.

Collage presentation: To develop the artistic talent of our participants, collage was introduced. A collage is a technique of art composed of numerous materials assembled from different forms, thus creating a new whole. To prepare decorative collage, participants assembled their beautiful variety of pictures from newspapers, journals, brochures, magazines, books, photographs, and so on the topic "health care" (Hartmann et al., 2012). The prepared collage charts were fabulously decorated using creative material and were used for presentation.

Photoshoot description: To develop creativity and description skills photoshoot activity was introduced on the topic "my best clicked photo" (Lavalle \& Briesmaster, 2017). Participants used smartphones and iPhones to participate in photoshoot activities. Learners showcased their artistic talent by shooting their best snaps from various corners of the beautiful campus. Description of my best photoshoot helped participants' to apply critical thinking skills to give their presentations. It helped them give description details using adjectives, prepositions, verbs, adverbs to enrich their spoken proficiency.

Group discussion: To develop spontaneous public speaking skills, a formal group discussion was introduced on the topic "positive and negative effects of a technology" (Savage \& Mayer, 2012, p. 108) to make participants share similar ideas on the given topic. The participants were seated in an inward-facing circle divided into a group of six and were given a five-minute time limit to discuss the topic. The participants shared their views on the importance of technology, the positive and negative impact of technology, and technology usage in the present scenario. The participants were informed about showcasing spontaneity, taking a chance to communicate, using content knowledge, vocabulary, maintaining eye contact, and focusing on nonverbal 
communication while participating in group discussion (Wang, 2011). It was observed that many participants observed the rules while participating in group discussion.

Chinese whispers game: To develop the art of attentive listening skills, the Chinese whispers game was introduced as cited by (Jahara, 2017). It is a fun and humorous game conducted to check the listening proficiency of participants by receiving, understanding, evaluating, remembering, and responding to the accurate response provided on a given proverb. To implement this activity in English Café, the participants were seated in an inward-facing circle. The number of participants were six. The researchers introduced a simple proverb, a picture speaks a thousand words by whispering it to one of the participants. The first listener is the initiator in the group, and this listener has to pass information to the second listener with lucidity to be passed to the rest of the participants until it reaches the last participant who has to repeat aloud what she heard as cited by (Jahara, 2012). This is then compared to the original sentence to check for the erroneous responses given by participants. This activity helps to show how a message gets lost while travelling: what we listen to and what we ignore; how we summarize, interpret, and recreate while listening and speaking.

\section{Objectives of Learning Activities}

Pronunciation, listening, and speaking skills prospers with active interaction between teachers and students. The instructional activities used in the linguistic club were carefully designed and selected from the curriculum to improve participant's communicative competence in English Café. The researchers motivated students before initiating an activity, as motivation prepares them to participate and lessen their anxiety levels actively. They learned effective learning tactics continuously while performing the activities. This helped them develop an acquaintance with the usage of vocabulary and English as a foreign language effortlessly.

One of the important aspects of foreign language teaching and learning is English pronunciation. Because it impacts learners' communicative competence and performance. Lack of pronunciation skills reduces learners' self-confidence and limit their social interactions. EFL teachers can help their learners obtain the necessary skills of pronunciation they need for effective communication (Gilakjani \& Sabouri, 2016).

\section{Learning Activities and Their Potential Benefits}

Practicing sounds helped to develop a perception of sounds, particularly by repetition and rehearsing sounds with suitable examples. Phonemic word squares helped to develop pronunciation by attention focusing, anticipating sounds, and inferencing the phonemes in word squares. Pictionary helped to develop vivid mental images, guessing mental images and inferencing the given picture. Tic-tac-toe helped to develop vocabulary by attention focusing, guessing the right word, anticipation, and inferencing the word in a meaningful sentence. Charades helped to develop the art of listening by attention focusing, guessing the right word, anticipation, inferencing, maintain eye contact, facial expressions, gestures, and posture. Brainstorming helped to improve attention focusing, learn new words, order words, and phrases, create a mental image, associate with content knowledge, and inference the word order.

Poem recital helped to improve their physical presence, rehearsing the poem, powerful internalization, tone of voice and delivery style, maintaining eye contact, facial expressions, gestures, and posture. Storytelling helped in associating with previous knowledge, creating a plot and content, creating vivid images, sharing the narrative details, paid selected attention to content, 
style of delivery, maintaining eye contact, facial expressions, gestures, and posture. Role-play helped to recapitulate knowledge, attention focusing, sharing the narrative details, associate with familiar concepts, highlight related points using placards, cooperating with peers, maintaining eye contact, facial expressions, gestures, and posture. Just a minute helped in the recapitulation of knowledge, the anticipation of a topic, attention focusing, generating an idea for a presentation, associating with familiar concepts without repetition, highlighting related points, maintaining eye contact, facial expressions, gestures, and posture. Ice breaker chain helped in attention focusing, associating with familiar concepts, remembering the chain without breaking, inferencing the information, maintaining eye contact, facial expressions, gestures, and posture. Ad-show helped in the recapitulation of knowledge, attention focusing, creating vivid images for the presentation, associating familiar concepts with advertisements, rehearsing the advertisement, cooperating with peers, maintaining eye contact, facial expressions, gestures, and posture. Collage presentation helped in the recapitulation of knowledge, attention focusing, self-monitoring of details, deciding in advance the specific details for presentation, highlighting related points, cooperating with peers, maintaining eye contact, facial expressions, gestures, and posture. Photoshoot description helped in attention focusing, previewing their photoshoots for presentation, associating with familiar concepts, self-monitoring of the details, highlighting related points in the description, maintaining eye contact, facial expressions, gestures, and posture. Group discussion helped in the recapitulation of content knowledge, attention focusing, creating an idea for the discussion, associating with familiar concepts, associating with previous knowledge, highlighting related points, guess what happens next, taking the initiative to talk, cooperating with peer's, maintaining eye contact, facial expressions, gestures, and posture. Chinese whispers helped in attention focusing, creating a mental image of the given proverb, associating with the knowledge to infer the appropriate proverb, cooperating with peers, paid selected attention, guessing what happens next, and highlighting the result.

Thus, from the previously discussed activities and their benefits, every participant needs some kind of strategies to help them control, their emotions, attitudes and values. Learning strategies help learners facilitate their own learning processes and they involve in developing motivation towards learning.

\section{Results}

\section{Pre-Café Scores}

Student abilities were measured for pronunciation and communication skills before attending the Café. Tables 1 and 2 show the overall assessments. Scores were divided into high and low categories.

In Table 1 and Table 2, the participant's performance was evaluated based on their level of accent, level of stress, and level of tone in pronunciation activities, and we used a measuring scale of 1-for low proficiency level and 2-for high proficiency level. Most participants were low achievers initially in pronunciation and vocabulary-building activities. The participants were given ear training in vowels and consonant phonemes in Café activities. 
Table 1

Pronunciation Skills in English Café for Level 1 Students, Pre-Café Intervention

\begin{tabular}{lllll}
\hline Activity & Level of accent & Level of stress & Level of tone & Proficiency level \\
\hline Practicing sounds & 1 & 1 & 1 & Low \\
Phonemic word square & 1 & 1 & 1 & Low \\
Pictionary & 1 & 1 & 1 & Low \\
Tic-tac-toe & 1 & 1 & 1 & Low \\
Charades & 1 & 1 & 1 & Low \\
Brainstorming & 1 & 1 & 1 & Low \\
\hline
\end{tabular}

Scale $1=$ low proficiency level, $2=$ high proficiency level

Table 2

Pronunciation Skills in English Café for Level 2 Students, Pre-Café Intervention

\begin{tabular}{lllll}
\hline Activity & Level of accent & Level of stress & Level of tone & Proficiency level \\
\hline Practicing sounds & 1 & 1 & 2 & Low \\
Phonemic word square & 1 & 2 & 1 & Low \\
Pictionary & 1 & 1 & 2 & Low \\
Tic-tac-toe & 1 & 2 & 2 & High \\
Charades & 1 & 1 & 2 & Low \\
Brainstorming & 1 & 1 & 2 & Low \\
\hline
\end{tabular}

Scale $1=$ low proficiency level, 2 = high proficiency level

Table 3

Communication Skills in English Café for Level 1 Students, Pre-Café Intervention

\begin{tabular}{|c|c|c|c|c|c|c|}
\hline Activity & $\begin{array}{l}\text { Content } \\
\text { knowledge }\end{array}$ & $\begin{array}{l}\text { Word } \\
\text { order }\end{array}$ & Grammar & Pronunciation & $\begin{array}{l}\text { Nonverbal } \\
\text { communication }\end{array}$ & $\begin{array}{l}\text { Proficiency } \\
\text { level }\end{array}$ \\
\hline Poem recital & 1 & 1 & 1 & 1 & 1 & Low \\
\hline Storytelling & 1 & 2 & 1 & 1 & 2 & Low \\
\hline Role-play & 1 & 1 & 2 & 1 & 2 & Low \\
\hline Extempore & 2 & 1 & 1 & 1 & 1 & Low \\
\hline $\begin{array}{l}\text { Ice breaker } \\
\text { chain }\end{array}$ & 2 & 2 & 1 & 1 & 1 & Low \\
\hline Ad-show & 2 & 2 & 1 & 1 & 1 & Low \\
\hline $\begin{array}{l}\text { Collage } \\
\text { presentation }\end{array}$ & 2 & 1 & 1 & 1 & 2 & Low \\
\hline $\begin{array}{l}\text { Photo-shoot } \\
\text { description }\end{array}$ & 2 & 1 & 1 & 1 & 2 & Low \\
\hline $\begin{array}{l}\text { Group } \\
\text { discussion }\end{array}$ & 1 & 1 & 1 & 1 & 1 & Low \\
\hline $\begin{array}{l}\text { Chinese } \\
\text { whispers } \\
\text { game }\end{array}$ & 1 & 1 & 1 & 1 & 1 & Low \\
\hline
\end{tabular}


Scale $1=$ low proficiency level, $2=$ high proficiency level

In Table 3 and Table 4, the participant's performance was evaluated based on their content knowledge, word order, grammar, pronunciation, and nonverbal communication, and we used a measuring scale of 1-for low proficiency level and 2 for high proficiency level. Most participants were low achievers initially in listening and speaking activities. The participants were given basic training before performing speaking activities. Linguistic competence is the ability to use the grammar, syntax, and vocabulary of a language correctly. When participants clearly understand the purpose of the given activity and showcase communicative ability, it will help them overcome language barriers and showcase competence to achieve their goal towards EFL as a target language.

\section{Table 4}

Communication Skills in English Café for Level 2 Students, Pre-Café Intervention

\begin{tabular}{lllllll}
\hline Activity & $\begin{array}{l}\text { Content } \\
\text { knowledge }\end{array}$ & $\begin{array}{l}\text { Word } \\
\text { order }\end{array}$ & Grammar & Pronunciation & $\begin{array}{l}\text { Nonverbal } \\
\text { communication }\end{array}$ & $\begin{array}{l}\text { Proficiency } \\
\text { level }\end{array}$ \\
\hline Poem recital & 1 & 1 & 1 & 1 & 1 & Low \\
Storytelling & 1 & 2 & 1 & 1 & 2 & Low \\
Role-play & 1 & 1 & 2 & 1 & 2 & Low \\
Extempore & 2 & 1 & 1 & 1 & 1 & Low \\
$\begin{array}{l}\text { Ice breaker } \\
\text { chain }\end{array}$ & 2 & 2 & 2 & 1 & 1 & High \\
$\begin{array}{l}\text { Ad-show } \\
\begin{array}{l}\text { Collage } \\
\text { presentation }\end{array}\end{array}$ & 2 & 2 & 1 & 1 & 1 & Low \\
$\begin{array}{l}\text { Photo-shoot } \\
\text { description }\end{array}$ & 2 & 1 & 2 & 1 & 1 & Low \\
$\begin{array}{l}\text { Group } \\
\text { discussion }\end{array}$ & 1 & 1 & 1 & 1 & 2 & Low \\
$\begin{array}{l}\text { Chinese } \\
\text { whispers } \\
\text { game }\end{array}$ & 1 & 1 & 1 & 1 & 1 & Low \\
\hline Sal & 1 & 1 & 1 & & 1 & Low
\end{tabular}

Scale $1=$ low proficiency level, 2 = high proficiency level

\section{Post-Café Scores}

\section{Pronunciation Skills}

After sufficient ear training, the participant's voice was recorded to identify their pronunciation and articulation of English phonemes. Most participants mastered the sounds, but they were less competent in distinguishing the vowel sounds than consonant sounds. 
In Table 5 and Table 6, the participant's performance was once again evaluated based on their level of accent, level of stress, and level of tone in pronunciation activities, and we used a measuring scale of 1-for low proficiency level and 2 for high proficiency level after post Café intervention. Initially, the participants were not competent speakers of the English language and the foreign accent was a major barrier to understand the correct pronunciation. But exposure in English Café has shown a remarkable change in participant's performance in all activities. The best way to improve one's performance in English pronunciation is to practice.

According to Chang (2005), pronunciation practice is a methodology meant for EFL teachers who have little background in phonetics or phonology and those who feel a need for expansion in their lesson repertoire. It is noted that many instructors are reluctant to teach pronunciation in adult EFL classrooms, often because of lack of formal training. However, significant number of EFL students want pronunciation instruction. Although stand-alone pronunciation courses for second-language (L2) learners exist, many students cannot gain access to them. One approach to meeting the needs of both instructors and students is for general-skills L2 textbooks to include pronunciation activities (Derwing et al., 2012).

According to (Zhaning \& Enhua, 2012), while teaching the target language, the focus on listening and speaking activities in classroom should be to foster the multimodal communicative competence that gives priorities to language competence.

It was observed that a majority of participants have lots of confusion in distinguishing between the voiceless bilabial plosive /p/ with voiced bilabial plosive /b/ sound. Many participants pronounce / p/ pay as bay and / b/ back as pack. Vowels posed a greatest problem to many participants, they were confused to distinguish between the close front vowel /I/ sit with close-mid front vowel /e/ set. Some participants were confused to distinguish between the short vowel / I/ pit with long vowel /i:/ key. It is observed that a majority of participants were confused to distinguish the long vowel sound / $\mathrm{a}$ :/ and failed to produce the acceptable sound patterns. A lot of ear training was given to participants and were repeatedly asked to pronounce the phonemes every day to overcome fossilized pronunciation errors and problems due to lack of proper phonemic training given in their school level.

Initially, the participants showed difficulty and had a problem recognizing the consonant and vowel phonemes. It is observed that majority of the participants mastered the sounds in the phonemic inventory but they were less competent in distinguishing the vowel sounds compared to consonant sounds.

It was observed that few participants do not know initially how to distinguish the short vowel sound /æ/ as in cap or long vowel sound /a:/ as in car. It was observed that a majority of participants after sufficient training in English Café improved to identify the sounds of English to fill the phonemic word squares. For example, / i:/ beach, bean, cheese and knees, / æ/ bat, tap, cap and sat /e/ sell, tell, set, yet, / o:/ tall, talk, call, laws and so on.

It was observed that a majority of participants participated reasonably well in drawing the given pictures like mouse, nail, tail, pan, map, rail and so on in pictionary to their team members and mime the vocabulary accurately.

It was observed that a majority of participants participated reasonably well in tic-tac-toe scores on the given nouns like an apartment, campus, dormitory, computer and so on verbs like, exercise, help, take, give and so on adjectives like modern, awake, wonderful, pregnant and so on, adverbs like suddenly, however, alone and so on to make meaningful sentences of their own to complete the tic-tac-toe squares on the board.

It was observed that a majority of participants participated reasonably well in charades game on the given vocabulary like, headache, stomachache, wrinkles, smoke, overweight, heart, 
healthy, chronic and so on to mime to their team members using their eye contact, facial expressions and gestures to perform well.

It was observed that a majority of participants used good brainstorming vocabulary like tomato sauce and cheese for taste, garlic, oily and cheesy for smell, tempting and delicious for appearance, shrimp, olives, pepperoni for preparation and types, waiting in line, eating with family at the garden for context to discuss their favourite food pizza, pasta and so on in brain storming activity.

The present research study has revealed that teachers prepare learners for pronunciation, listening and speaking activities in the classroom. However, the major problem is that most of these activities are not done consciously with an aim to help participants improve their pronunciation, listening and speaking skills to achieve the desired objectives.

\section{Table 5}

Pronunciation Skills in English Café for Level 1 Students, Post-Café Intervention

\begin{tabular}{lcccc}
\hline Activity & Level of accent & Level of stress & Level of tone & Proficiency level \\
\hline Practicing sounds & 1 & 2 & 2 & High \\
Phonemic word square & 2 & 2 & 2 & High \\
Pictionary & 1 & 2 & 2 & High \\
Tic-tac-toe & 2 & 2 & 2 & High \\
Charades & 1 & 2 & 2 & High \\
Brainstorming & 2 & 2 & 2 & High \\
\hline
\end{tabular}

Scale $1=$ low proficiency level, 2 = high proficiency level

Table 6

Pronunciation Skills in English Café for Level 2 Students, Post-Café Intervention

\begin{tabular}{lcccc}
\hline Activity & Level of accent & Level of stress & Level of tone & Proficiency level \\
\hline Practicing sounds & 2 & 2 & 2 & High \\
Phonemic word square & 2 & 2 & 2 & High \\
Pictionary & 2 & 2 & 2 & High \\
Tic-tac-toe & 2 & 2 & 2 & High \\
Charades & 2 & 2 & 2 & High \\
Brainstorming & 2 & 2 & 2 & High \\
\hline
\end{tabular}

Scale 1 = low proficiency level, 2 = high proficiency level

\section{Communication Skills}

In Table 7 and Table 8, the participant's performance was once again evaluated based on their content knowledge, word order, grammar, pronunciation, and nonverbal communication, and we used a measuring scale of 1-for low proficiency level and 2 for high proficiency level after post café intervention. Listening to different words involves recognition of the sound of words, perception of sound, their accent and their tonal variation. Decoding of spoken words requires the ability to perceive and recognize speech sounds and sound patterns accurately, and the way sounds combine to form utterances and their implied meaning. It was observed that some of the participants had problems in processing and comprehending the speaking activities initially but it was observed that the majority of participants after post Café intervention improved in their communicative competence remarkably. 
Table 7

Communication Skills in English Café for Level 1 Students, Post-Café Intervention

\begin{tabular}{|c|c|c|c|c|c|c|}
\hline Activity & $\begin{array}{l}\text { Content } \\
\text { knowledge }\end{array}$ & $\begin{array}{l}\text { Word } \\
\text { order }\end{array}$ & Grammar & Pronunciation & $\begin{array}{l}\text { Nonverbal } \\
\text { communication }\end{array}$ & $\begin{array}{l}\text { Proficiency } \\
\text { level }\end{array}$ \\
\hline Poem recital & 2 & 2 & 2 & 1 & 2 & High \\
\hline Storytelling & 2 & 2 & 2 & 2 & 2 & High \\
\hline Role-play & 2 & 2 & 2 & 1 & 2 & High \\
\hline Extempore & 2 & 2 & 2 & 2 & 2 & High \\
\hline $\begin{array}{l}\text { Ice breaker } \\
\text { chain }\end{array}$ & 2 & 2 & 1 & 2 & 2 & High \\
\hline Ad-show & 2 & 2 & 1 & 2 & 2 & High \\
\hline $\begin{array}{l}\text { Collage } \\
\text { presentation }\end{array}$ & 2 & 2 & 2 & 2 & 2 & High \\
\hline $\begin{array}{l}\text { Photo-shoot } \\
\text { description }\end{array}$ & 2 & 2 & 2 & 2 & 2 & High \\
\hline $\begin{array}{l}\text { Group } \\
\text { discussion }\end{array}$ & 2 & 2 & 1 & 2 & 1 & High \\
\hline $\begin{array}{l}\text { Chinese } \\
\text { whispers } \\
\text { game }\end{array}$ & 2 & 2 & 1 & 1 & 1 & Low \\
\hline
\end{tabular}

Scale 1 = low proficiency level, 2 = high proficiency level

Table 8

Communication Skills in English Café for Level 2 Students, Post-Café Intervention

\begin{tabular}{|c|c|c|c|c|c|c|}
\hline Activity & $\begin{array}{l}\text { Content } \\
\text { knowledge }\end{array}$ & $\begin{array}{l}\text { Word } \\
\text { order }\end{array}$ & Grammar & Pronunciation & $\begin{array}{l}\text { Nonverbal } \\
\text { communication }\end{array}$ & $\begin{array}{l}\text { Proficiency } \\
\text { level }\end{array}$ \\
\hline Poem recital & 2 & 2 & 1 & 2 & 2 & High \\
\hline Storytelling & 2 & 2 & 2 & 2 & 2 & High \\
\hline Role-play & 2 & 1 & 2 & 2 & 2 & High \\
\hline Extempore & 2 & 2 & 1 & 2 & 2 & High \\
\hline $\begin{array}{l}\text { Ice breaker } \\
\text { chain }\end{array}$ & 2 & 2 & 2 & 2 & 1 & High \\
\hline Ad-show & 2 & 2 & 2 & 2 & 2 & High \\
\hline $\begin{array}{l}\text { Collage } \\
\text { presentation }\end{array}$ & 2 & 2 & 2 & 2 & 2 & High \\
\hline $\begin{array}{l}\text { Photo-shoot } \\
\text { description }\end{array}$ & 2 & 2 & 2 & 2 & 2 & High \\
\hline $\begin{array}{l}\text { Group } \\
\text { discussion }\end{array}$ & 2 & 2 & 2 & 2 & 1 & High \\
\hline $\begin{array}{l}\text { Chinese } \\
\text { whispers } \\
\text { game }\end{array}$ & 2 & 2 & 2 & 1 & 2 & High \\
\hline
\end{tabular}




\section{Conclusion}

Most participants had a positive urge to enhance their communication skills. They were highly motivated towards learning the language and sounds of English to develop their communication, pronunciation, and listening ability. Finally, students exhibited more enthusiasm and motivation in learning English language by participating in activities related to the content and context in the English Café. The participants had limited exposure to pronunciation, listening, and speaking activities before participating in English Café. While selecting relevant learning activities, it is important to decide how relevant they are to students and how learning outcomes are achieved. We observed that a majority of participants showed positive responses to enrich their pronunciation, listening, and speaking skills.

A majority of participants showed positive attitude towards the listening and speaking activities and as a result learned new vocabulary for word order improved their grammar and pronunciation skills developed their content knowledge and nonverbal communication with the researchers' guidance and constant practice from one activity to another. It was observed that the participants improved their ability to work in a group setting by associating with previous knowledge, recapitulating, generating, negotiating and accepting ideas.

At first, the participants were over-reliant on translating information from their mother tongue to EFL but after getting sufficient training from pronunciation activities, they were no longer anxious by the difficult words or pronunciation problems and were able to perform the activities better. They were able to perform all the given activities step by step each week which has resulted in a development of their interpretation skills and communicative competence.

It was observed that participants practiced the lyric poem with good tone of voice and style of delivery to get good scores on the measuring scale. Participants recited the lyric poem "My Love is Like A Red, Red Rose" with physical presence and internalization to perform better. (ibid.p.120).

It was observed that participants practiced sharing their dangerous, unusual and exciting experiences in the desert through their fact and fiction stories. A few participants created their best nonfiction stories with their amazing introduction, setting, storyline, catchy outline, creative content, artistic characters, peak action, vivid descriptions, and resolution.

It was observed that the participants worked on the theme littering and the hazards it causes to the environment in role-play. They used placards to show their message, "no plastics" saying that every individual is responsible for reducing the usage of plastics in deserts to retain its serenity and natural beauty. It was observed that a majority of participants used smile "emojis" to share their ideas on smile. They shared that they love smiley emojis, smiley advertisements, and smiley faces. They gave their content information to the participants to keep smiling and spread happiness. It was observed that a majority of participants used names of chocolates to introduce themselves like "My-self galaxy-Gadha", she is "ferrero rocher-Fouzia", the next girl is "kit-kat-Kaznah" and so on. This activity encouraged the participants to memorize the chain and know each other through a bar of chocolate.

It was observed that a majority of participants created "interesting and boring" commercials mostly on lifestyle. However, one team shaped a dramatic, thought-provoking commercial, a public service announcement against the hazards of junk food and its effects in the cafeterias. The participants performing in the commercial warned students to switch on to a healthy diet with their ad-show concept.

It was observed that a majority of participants clicked their "my best selfie" and "my bestclicked photo" to give description of their photos using adjectives, adverbs and so on. A majority 
of participants learnt to give description of minute details using appropriate grammatical details and vocabulary. It was observed that a majority of participants showcased their artistic talent by decorating beautiful collage on a healthy diet, exercise machines, diet chart, first aid kit, simple medications on "health care". This activity helped participants describe sensory details of their collage to give life to their art. It was observed that participants gave their opinion on the impact of technology. The way it's making their own life easy in a small province like Al-Asyah to get connected to the world. They also agreed that today's youngsters are addicted to technology. This activity helped them to showcase their ideas and spontaneity towards English as a foreign language.

It was observed that participants learnt to interpret the information accurately through Chinese whispers game. This activity helped participants to show how a message gets lost while travelling: what we listen to and what we ignore; how we summarize, interpret, and recreate while listening and speaking. They understood the importance of listening well to communicate well. The findings revealed that the participants improved their communicative competence through preferred learning style, motivation, self-interest, willingness to communicate, and usage of strategies.

An ardent English teacher has the flair of making the complicated simple, thereby making the arduous more appealing. It was observed that students rejoiced with zeal and enthusiasm participating in the activities organized by English Café. Language acquisition is a demanding job, but if the style of delivery and approach is changed and made learner-friendly, learning becomes joyful and long-lasting.

\section{Limitations}

The present research study has focused on the descriptive-analytical method using a questionnaire adapted to impart pronunciation, listening, and speaking activities in our linguistic club named English Café in Al-Asyah province. It did not focus on other communication skills or other universities. However, an attempt was made to get an idea of the different skills taught to the students at the undergraduate level.

\section{Acknowledgments}

The researchers thank the Deanship of Scientific Research, Qassim University, for funding this project's publication. Our thanks to the faculty in the Department of English Language and Translation, College of Sciences and Arts at Al-Asyah. We are grateful to the first and second levels participants from the Department of English Language and Translation. Finally, we would like to thank the anonymous reviewers for their contribution to this research project.

\section{Notes}

1. The government of the Kingdom of Saudi Arabia has undertaken many reforms to raise the level of English proficiency amongst all Saudi learners.

2. English is not acquired as L2 in Saudi Arabia but rather taught as a foreign language by EFL-trained teachers.

3. Saudiasation is meant to be used for the Saudi Nationalization scheme, which is one of the most recent policies of the Kingdom of Saudi Arabia implemented by the Minister of Labor and Social Development, whereby Saudi enterprises and companies are required to replace residents and foreigners in their workplace with Saudi nationals up to certain levels. 
4. Vision 2030 is a strategic framework to reduce Saudi Arabia's dependence on oil, diversify its economic and public service sectors such as education, health, infrastructure, recreation, and tourism that Crown Prince Mohammad Bin Salman announced on April 25, 2016.

5. An order of the Custodian of the Two Holy Mosques King Salman bin Abdul-Aziz was issued in 2015 to merge the Ministries of Education and Higher Education into one Ministry under the name (Ministry of Education) to improve educational outcomes, develop curricula and reduce the gap between public education and higher education.

\section{References}

Alhawsawi, S. (2014). Investigating student experiences of learning English as a foreign language in a preparatory programme in a Saudi university (Order No. U633396). Available from ProQuest Dissertations \& Theses Global. (1683610316). Retrieved from https://wwwproquest-com.sdl.idm.oclc.org/dissertations-theses/investigating-student-experienceslearning/docview/1683610316/se-2?accountid=142908

Amrullah, A. Z. (2015). Developing language games to teach speaking skill for Indonesian senior high school learners. JEELS (Journal of English Education and Linguistics Studies, 2(2), 13-33.

Atmaca, Ç. (2018). Contrasting perspectives of pre-service and in-service English teachers: What should be an English teacher's role? International Journal of Languages' Education and Teaching, 6(1), 143-153. Retrieved from https://www-proquestcom.sdl.idm.oclc.org/scholarly-journals/contrasting-perspectives-pre-serviceenglish/docview/2101360030/se-2?accountid $=142908$

Bu, Z., \& Guo, E. (2012). The teaching design of college English viewing-listening-and-speaking class from the perspective of social semiotics. Qingdao Daxue Shifanxueyuan Xuebao/Journal of Teachers College Qingdao University, 29(1), 21-26.

Chang, M. (2005). Pronunciation practice activities: A resource book for teaching English pronunciation. Canadian Modern Language Review, 61(3), 436-439. https://doiorg.sdl.idm.oclc.org/10.1353/cml.2005.0013

Demir, A. N., \& Zaimoğlu, S. (2021). The relationship between foreign language anxiety and decision-making strategies among university students. Journal of Language \& Linguistics Studies, 17, 18-32. doi:10.17263/jlls.903294

Derwing, T. M., Diepenbroek, L. G., \& Foote, J. A. (2012). How well do general-skills ESL textbooks address pronunciation? TESL Canada Journal, 30(1), 22-44. Retrieved from http://search.ebscohost.com/login.aspx?direct=true \&db=ehh\&AN=89244514\&site=ehostlive

Dufresne, A. \& Turcotte, S. (1997). Cognitive style and its implications for navigation strategies. In Boulay, B. \& Mizoguchi, R. (Eds.) Artificial Intelligence in Education (pp. 287-293). Knowledge and Media in Learning Systems IOS Press.

Dunn, R. S., \& Griggs, S. A. (2000). Practical approaches to using learning styles in higher education. Greenwood Publishing Group.

Durling, D, Cross, N., \& Johnson, J. (1996). Personality and leaning preferences of learners in design and design-related disciplines. Proceedings of the International Design and Technology Educational Research and Curriculum Development Conference. (IDATER 96), Loughborough University.

Ellis, R. (1994). The study of second language acquisition. Oxford University Press. 
Ford, N. \& Miller, D. (1996). Gender differences in internet perceptions and use. Aslib Proceedings 48, 183-192.

Gilakjani, A. P., \& Sabouri, N. B. (2016). How can EFL teachers help EFL learners improve their English pronunciation? Journal of Language Teaching \& Research, 7(5), 967-972. doi:10.17507/jltr.0705.18

Hancock, M. (2003). English pronunciation in use (2 ${ }^{\text {nd }}$ ed.). Cambridge University Press.

Hartmann, P., Mentel. J., \& Motala, A. (2012). Interactions reading/writing. McGraw-Hill.

Holscherl, C., \& Strubel, G. (2000). Web search behaviour of internet experts and newbies, Computer Networks, 33(1), 337-346.

Jahara, S.F. (2012). Digital projects to induce language learning. ICELL-2012, International Conference on English Language and Literature. International Academic and Industrial Solutions (pp. 33).

Jahara, S.F. (2012). Practicing innovative ideas to develop listening proficiency of L2 learners. ICOPE-2012, International Conference on Professional English (pp. 518-519).

Jahara, S.F. (2013). Tech savvy global children. ICELL-2013, International Conference on English Language and Literature. International Academic and Industrial Solutions (pp. 177-181).

Jahara, S.F. (2017). Listening as a catalyst., In Dalal, G. \& Gulati, V. (Eds.), Innovations in English language teaching in India: Trends in language pedagogy and technology (pp. 17). Lexington Books, Rowman and Littlefield Publications.

Lavalle, P. I., \& Briesmaster, M. (2017). The study of the use of picture descriptions in enhancing communication skills among the 8th-grade students-learners of English as a foreign language. Inquiry in Education, 9(1), 1-14.

Mayer, R. E., \& Gallini, J. K. (1990). When is an illustration worth ten thousand words? Journal of Educational Psychology, 82, 715-726.

Ministry of Education. (n.d). The Emergence of the Ministry. (n.d.). www.moe.gov.sa. Retrieved February 15, 2021, from https://www.moe.gov.sa/en/aboutus/aboutministry/ Pages/About.aspx

Mooney, S. F., \& Little, A. (2020). Students writing poetry. Journal of Christian Nursing: A Quarterly Publication of Nurses Christian Fellowship, 37(2), 1-13. doi:10.1097/CNJ.0000000000000697

Pellicer, O.S., Mur, D. P., Gil, V., \& Delgado, C. V. (2020). Developing communication and thinking skills in English as a foreign language education undergraduate student: A proposal for a syllabus model. Onomazein: Revista De Linguística Y Traducción Del Instituto De Letras De La Pontificia Universidad Católica De Chile, 6. 104-125. doi: 10.7764/onomazein.ne6.06

Rahmah, A., \& Astutik, Y. (2020). Charades game: Does it affect students' learning on English vocabulary? EnJourMe (English Journal of Merdeka), 5(1), 75-89. doi:10.26905/enjourme. v5i1.4258

Reid, J. (1987). The learning style preferences of ESL students. TESOL Quarterly 21, 87-103.

Richards, J. C. \& Lockhart, C. (1996). Reflective teaching in second language classrooms. Cambridge University Press.

Riding, R., \& Rayner, S. (1998). Cognitive styles and learning strategies: Understanding style differences in learning and behavior. Routledge.

Savage, A. \& Mayer, P. (2012). Effective academic writing. (2 $2^{\text {nd }}$ ed.). Oxford University Press.

Stern, H. H. (1992). Issues and options in language teaching., In Lefkowitz, N. (Eds), Studies in Second Language Acquisition, Oxford: Oxford University Press. 
Tanka, J., \& Most, P. (2012). Interactions-1 listening \& speaking. (6 ${ }^{\text {th }}$ ed.). McGraw-Hill Education.

Tzvetomira, V. (2020) English as a Foreign Language in Saudi Arabia: New Insights into Teaching and Learning English, Australian Journal of Linguistics, 40(1), 135-137, doi: 10.1080/07268602.2019.1567299

Vision 2030. (2021). Available at: https://www.vision2030.gov.sa/en

Wallace, M. (1991). Training foreign language teachers. A reflective approach. ( $\left.1^{\text {st }} \mathrm{ed}\right)$. Cambridge University Press.

Wang, M. (2011). Using multimodal presentation software and peer group discussion in learning English as a second language. Australasian Journal of Educational Technology, 27(6), 907923. doi:10.14742/ajet.920.

Willing, K. (1987). Learning styles in adult migrant education. In Nunan, D. (Eds), NSW Adult Migrant Education Service.

Xiao, J. (2014). What do distance language tutors say about teacher motivation? Open Learning, 29(2), 145-159. https://doi-org.sdl.idm.oclc.org/10.1080/02680513.2014.931804

\section{Notes on Contributors}

Syed Farhat Jahara has received Ph.D. in English Language. She is an Assistant Professor at the Department of English Language and Translation, College of Sciences and Arts at Al-Asyah, Qassim University, Kingdom of Saudi Arabia. Her research interests include effective methods to improve listening and speaking skills, designing task-based activities based on learner needs, reflective teaching and personality development, soft skills, learning styles and learner strategies. ORCID ID: 0000-0002-2057-5982

Abbas Hussein Abdelrady has received Ph.D. in Applied Linguistics. He is an Assistant Professor at the Department of English Language and Translation, College of Sciences and Arts at Al-Asyah, Qassim University, Kingdom of Saudi Arabia. His research interests are teaching English as a foreign language, education policy and pedagogy. He is focused on Linguistics, Historical Linguistics, Applied Linguistics, Psycholinguistics and Second Language Acquisition. ORCID ID: 0000-0002-7920-887X 